\title{
NOTUM Is Involved in the Progression of Colorectal Cancer
}

\author{
JONG HYUK YOON ${ }^{*}$, DAYEA KIM ${ }^{2 *}$, JAEYOON KIM ${ }^{3,4}$, HYEONGJOO LEE ${ }^{4}$, JAEWANG GHIM ${ }^{4}$, \\ BYUNG JUN KANG ${ }^{5}$, PARKYONG SONG ${ }^{5}$, PANN-GHILL SUH ${ }^{6}$, SUNG HO RYU ${ }^{5}$ and TAEHOON G. LEE ${ }^{4}$ \\ ${ }^{1}$ Department of Neural Development and Disease, Korea Brain Research Institute, Daegu, Republic of Korea; \\ ${ }^{2}$ New Drug Development Center, Daegu-Gyeongbuk Medical Innovation Foundation, Daegu, Republic of Korea; \\ ${ }^{3}$ School of Interdisciplinary Bioscience and Bioengineering and ${ }^{5}$ Department of Life Sciences, \\ Pohang University of Science and Technology (POSTECH), Pohang, Republic of Korea; \\ ${ }^{4}$ NovaCell Technology, Inc., Pohang, Republic of Korea; \\ ${ }^{6}$ School of Life Sciences, Ulsan National Institute of Science and Technology, Ulsan, Republic of Korea
}

\begin{abstract}
Background: There are limitations to current colorectal cancer (CRC)-specific diagnostic methods and therapies. Tumorigenesis proceeds because of interaction between cancer cells and various surrounding cells; discovering new molecular mediators through studies of the $C R C$ secretome is a promising approach for the development of CRC diagnostics and therapies. Materials and Methods: A comparative secretomic analysis was performed using primary and metastatic human isogenic CRC cells. Proliferation was determined by MTT and thymidine incorporation assay, migration was determined by wound-healing assay (ELISA). The level of palmitoleoyl-protein carboxylesterase (NOTUM) in plasma from patients with CRC was determined by enzymelinked immunosorbent assay. Results: NOTUM expression was increased in metastatic cells. Proliferation was suppressed by inhibiting expression of NOTUM. Knockdown of NOTUM genes inhibited proliferation as well as migration, with possible involvement of 338 and $c$-JUN N-terminal kinase in this process. The result was verified in patients with CRC. Conclusion: NOTUM may be a new candidate for diagnostics and therapy of $C R C$.
\end{abstract}

This article is freely accessible online.

*These Authors contributed equally to this work.

Correspondence to: Taehoon G. Lee, Ph.D., NovaCell technology, Inc., Pohang, Gyeongsangbuk-do, Republic of Korea. Tel: +82 542232475, Fax: +82 542232474, e-mail: taehoon@novacelltech.com; Jong Hyuk Yoon, Ph.D., Department of Neural Development and Disease, Korea Brain Research Institute, Daegu, South Korea. Tel: + 82 539808341, Fax: +82 539808399, e-mail: jhyoon@kbri.re.kr

Key Words: NOTUM, secretomics, colorectal cancer, migration, diagnosis.
Colorectal cancer (CRC) is the fourth most common malignancy and a leading cause of cancer-related mortality worldwide (1). Recent estimates suggest that the burden of CRC is expected to increase by $60 \%$ by 2030 , with more than 2.2 million new cases and 1.1 million deaths (2). A large proportion of this burden could be prevented either by the screening and detection of this cancer at early stages when chances of a cure are substantially higher than at later stages, or by the detection and removal of precancerous lesions $(3,4)$. Nevertheless, primary screening faces limitations in terms of invasiveness, available capacities, costs, inconvenience, and adherence $(5,6)$. Although blood-based protein biomarkers such as carcinoembryonic antigen and carbohydrate antigen 19-9 are already utilized in the clinical setting, they cannot be used alone to screen or diagnose cancer because levels of these markers can be abnormal for reasons other than cancer, such as hepatitis and inflammatory bowel disease (7). Thus, there is an urgent need for new biomarkers and molecular targets with relatively high sensitivity and specificity to CRC.

Solid tumors such as CRC are composed of malignant cells along with other stromal cells such as neoplastic, mesenchymal, and inflammatory cells (8). Cancer cells interact with other cells through secreted factors, orchestrating complex signaling pathways (9). Cancer cells secrete various factors including soluble factors and proteases that alter adjacent stromal cells toward a permissive and supportive microenvironment for tumor progression (10). This cancer 'secretome' has been receiving increased interest for the discovery of diagnostic or prognostic cancer biomarkers, and can be a good tool for elucidating cancer biology $(11,12)$. Therefore, a comprehensive analysis of the cancer secretome can lead to discovery of potential biomarkers or therapeutic targets as well as give a microscopic insight into the cancer microenvironment.

SW480 and SW620 CRC cell lines were derived from primary and metastatic tumors, respectively, from the same 
patient and have identical mutation profiles, but epigenetic differences (13). The monoclonal origin of these two cell lines was confirmed by the presence of shared marker chromosomes seen on cytogenetic analysis (14). Since variation due to genetic background can largely be disregarded for these two cell lines, they constitute a unique model for studying CRC progression and metastasis. Some studies have compared the two cell lines to find biomarkers using proteomic analysis $(11,15,16)$. However, it is still necessary to study the secretome of these cells because of insufficient information regarding biomarkers or therapeutic targets.

Here, we performed a comparative secretomic analysis of conditioned medium from SW480 and SW620 cell cultures to characterize their CRC secretomes and to identify CRC-derived proteins and those associated with metastatic phenotype. The strategy for our research is outlined in Figure 1A.

\section{Materials and Methods}

Cell cultures. SW480 and SW620 CRC cell lines obtained from the ATCC (Manassas, VA, USA) were grown in Roswell Park Memorial Institute (RPMI) 1640 medium (Lonza Group, Basel, Switzerland) containing $10 \%$ fetal bovine serum and $1 \%$ penicillin/streptomycin (both from Gibco Life Technologies, Gaithersburg, MD USA) at $37^{\circ} \mathrm{C}$ with $5 \% \mathrm{CO}_{2}$. Cells were monitored using a microscope (LSM 510 Meta; Ziess, Germany).

Preparation of conditioned medium. SW480 and SW620 cells were washed three times with phosphate-buffered saline (PBS). Conditioned medium was prepared by adding unsupplemented RPMI 1640 (no serum, phenol red, or antibiotics) to SW480 or SW620 cells, and incubating them for $24 \mathrm{~h}$ at $37^{\circ} \mathrm{C}$ with $5 \% \mathrm{CO}_{2}$. Conditioned medium was then collected and centrifuged at 2,100 $\times \mathrm{g}$ for $10 \mathrm{~min}$ (Combi514R; Hanil Science Industry, Gimpo, Korea). After discarding of pellets, supernatants were collected for the next procedure.

Sample preparation for mass spectrometric (MS) analysis. The supernatants were filtered through Amicon Ultra-15 Centrifugal Filter Unit (UFC900324; Millipore, Tullagreen, Carrigtwohill Co. Cork, Ireland) for desalting and decontamination. The filtered supernatants were lyophilized. For tryptic digestion, dried samples were reduced using $10 \mathrm{mM}$ dithiothreitol in $50 \mathrm{mM}$ ammonium bicarbonate (ABC) and alkylated using $100 \mathrm{mM}$ iodoacetamide in $50 \mathrm{mM}$ ammonium bicarbonate. Finally, each sample was treated with trypsin (Promega, Madison, WI, USA) at a 1:50 ratio for $12 \mathrm{~h}$ at $37^{\circ} \mathrm{C}$ and dried.

MS analysis. All MS analyses were carried out using a nano-liquid chromatography and MS system consisting of a high-performance liquid chromatography (HPLC) system (Agilent 1100; Agilent Technologies, Santa Clara, CA, USA) and a QSTAR quadrupole-TOF mass spectrometer (Applied Biosystems, Foster City, CA, USA; MDS SCIEX, Concord, ONT, Canada) equipped with a nano-electrospray ionization source. For high-resolution separation, a nanoscale RPC column (ZORBAX C18, $3 \mathrm{~mm}, 100 \AA$, 75 mm, i.d.; Agilent Technologies) was used. Mobile phase A consisted of HPLC-grade water containing $0.1 \%$ formic acid, and mobile phase B consisted of $84 \%$ HPLC-grade acetonitrile containing $0.1 \%$ formic acid. The separation was performed at a flow rate of $250 \mathrm{nl} / \mathrm{min}$, and the applied gradient was $0-40 \%$ B over $60 \mathrm{~min}$. For the tandem MS analysis, each scan cycle consisted of one full scan mass spectrum (m/z 400-1500) followed by three MS/MS events. Dynamic exclusion was activated for $1 \mathrm{~min}$ with a repeat count of 2 . This study used three biological replicates for each condition in MS analyses.

Database search for identified secretome proteins. Analyst QS 2.0 (AB Sciex, Framingham, MA, USA) was used for data acquisition. Mascot Daemon version 2.2.2 (Matrix Science, Boston, MA, USA) generated mascot generic format files from the raw data files. The mascot generic format files were searched against the concatenated database consisting of sequences of Homo sapiens and Bos taurus from UniProt/Swiss-Prot (release 2018_03, EMBL-EBI), and their reverse sequences using MASCOT software version 2.2.04. The following search parameters were applied for database search: two missed cleavages were allowed; carbamidomethylation (C) as a fixed modification; pyroglutamylation (N-term EQ), oxidation (M), and $N$-acetyl (protein) as variable modifications; and $+2,+3$, and +4 charge ions were included. Peptide tolerance was $30 \mathrm{ppm}$ and MS/MS tolerance was 0.5 Da. For peptide identification and protein assembly, MASCOT score $=15$ was used as the initial peptide filter, which estimated a $1 \%$ false discovery rate calculated using the target-decoy method (17). Proteins with no unique peptide or with only one spectral count were excluded identified. Proteins identified with a higher MASCOT score in the bovine database than that in the human database were also excluded from the list as they were considered as serum contaminants.

Quantitative analysis of MS results. In order to perform quantitative analysis of the identified proteins from two cell lines, the normalized spectral index based on the fragment ion intensity measurement was applied with modifications following a previous report (18). Briefly, the spectral index (SI) of each protein was calculated, which is the cumulative fragment ion intensity for identified peptides, and it was normalized $\left(\mathrm{SI}_{\mathrm{N}}\right)$ by dividing the total sum of SI for all identified proteins $\left(\mathrm{SI}_{\mathrm{T}}\right)$. To avoid taking logarithms for zero values, if no peptide was identified from a cell line, the spectral index was set as half the minimum value among all SI. The average SIN value from biological replicates in each group was acquired, and $\log 2$ ratio of normalized SI between the two groups, $\log _{2}\left(\mathrm{SI}_{\mathrm{N} \_\mathrm{A}} / \mathrm{SI}_{\mathrm{N} \_\mathrm{B}}\right)$, was compared. For bioinformatic study, quantitatively analyzed proteins were analyzed through the use of Ingenuity Pathway Analysis (IPA; Ingenuity ${ }^{\circledR}$ Systems, www.ingenuity.com). Canonical pathways which were predicted to be influenced by the differentially expressed proteins were ranked in order of significance.

Tetrazolium (MTT) assay. SW480 and SW620 cells were cultured in a 96-well culture plate at a density of 3,000 cells/well. After $24 \mathrm{~h}, 10 \mu \mathrm{g} / \mathrm{ml}$ of palmitoleoyl-protein carboxylesterase (NOTUM) antibody (ab106448; Abcam, Cambridge, UK) and IgG antibody were added and cells were incubated for a further $72 \mathrm{~h}$. After the medium was discarded, $0.5 \mathrm{mg} / \mathrm{ml}$ of MTT solution (Sigma-Aldrich, St. Louis, MO, USA) dissolved in serum-free medium was added and cells were incubated for $3 \mathrm{~h}$ at $37^{\circ} \mathrm{C}$ in an atmosphere with $5 \%$ $\mathrm{CO}_{2}$. The medium was then removed, and $100 \mu$ of dimethyl sulfoxide was added to each well of the 96-well culture plate. The plate was vortexed for $10 \mathrm{~min}$. Absorbance of the solution in each well was then measured at $540 \mathrm{~nm}$ using a Biotrak 2-plate reader (GE Healthcare, Chicago, IL, USA). 

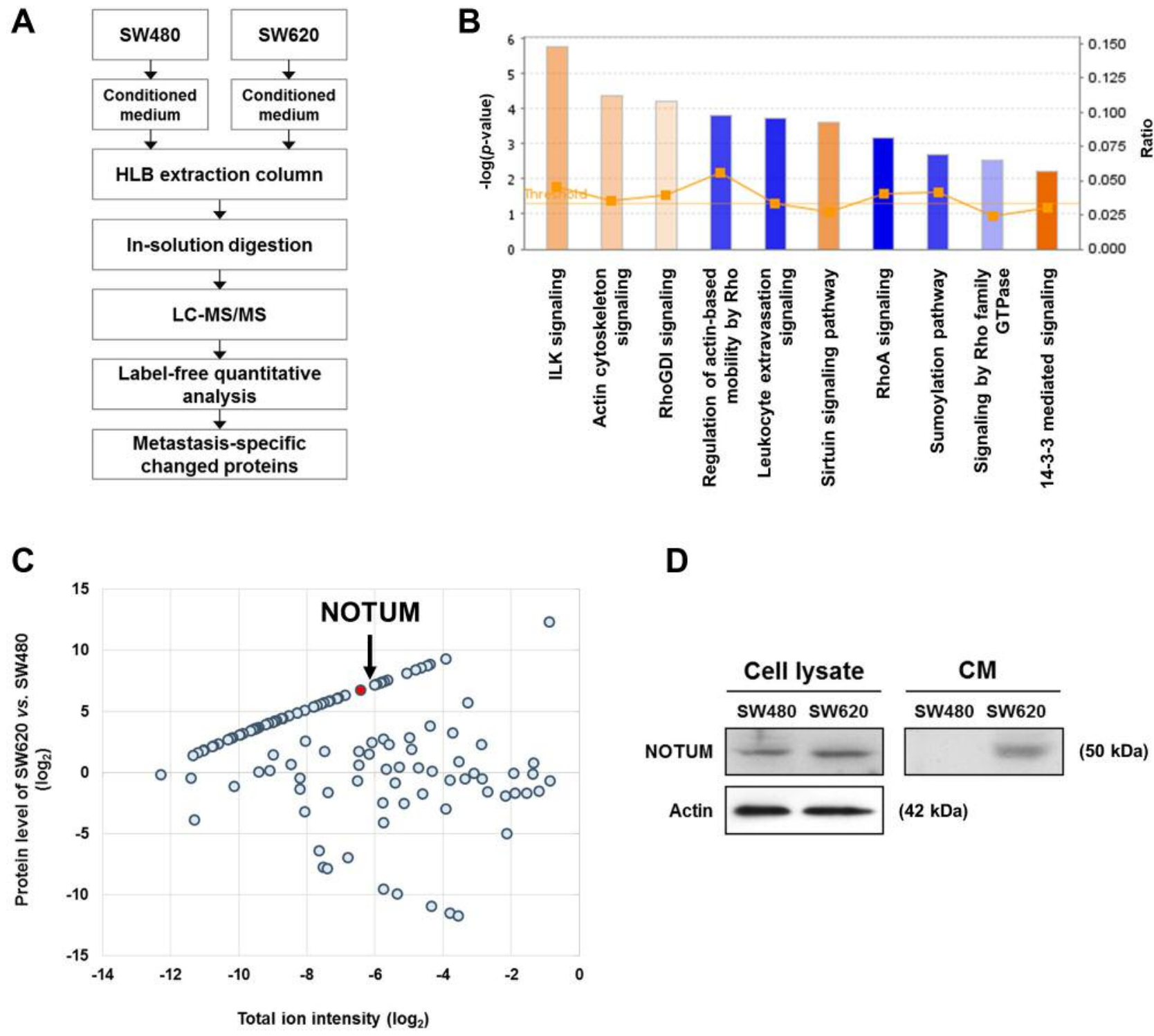

$(50 \mathrm{kDa})$

Figure 1. Proteomic analysis of SW480 and SW620 colorectal cancer cell secretomes. A: Experimental strategy. B: Ingenuity Pathway Analysis of the identified proteins. Orange indicates a canonical pathway that was activated. Blue indicates a canonical pathway that was deactivated. Parameters for the analysis were z-score cut-off $=0.5$ and $-\log (p$-value) $>1.3$. C: Virtual 2-D peptide map of SW620 vs. SW480 cells. The X-axis shows the total protein intensity, and the Y-axis shows the amount of individual proteins in SW620 vs. SW480 cell lines. Each dot indicates a secretory protein. The linear plot indicates the quantity of proteins in SW620 vs. those in SW480, where a protein level above 0 means more proteins secreted in SW620 than in SW480 cells. D: Immunoblot analysis for palmitoleoyl-protein carboxylesterase (NOTUM) in cell lysate and conditioned medium (CM).

Thymidine incorporation assay. SW480 and SW620 cells were seeded in a 96-well culture plate at a density of 3,000 cells/well. After $24 \mathrm{~h}$, anti-NOTUM small interfering RNA (siRNA) (GenePharma, Shanghai, China) and control siRNA (GenePharma) were added to the cells and plates were incubated for $4 \mathrm{~h}$ at $37^{\circ} \mathrm{C}$ in an atmosphere with $5 \% \mathrm{CO}_{2}$. Sequences of siRNA used are given in Table I. The medium was changed to growth medium and plates were incubated for a further $72 \mathrm{~h}$ at $37^{\circ} \mathrm{C}$ in an atmosphere with $5 \%$ $\mathrm{CO}_{2}$. After incubation, cells were treated with ${ }^{3} \mathrm{H}$-thymidine $(0.3$
$\mathrm{mCi} / 0.3 \mathrm{ml}$, each well) in serum-free medium for $6 \mathrm{~h}$ then $0.2 \mathrm{ml}$ of $10 \%$ trichloroacetic acid was added and plates were incubated at $4^{\circ} \mathrm{C}$ for $30 \mathrm{~min} ; 1 \mathrm{M} \mathrm{NaOH}$ was added to the plates which were incubated at $3^{\circ} \mathrm{C}$ for 25 min. Radioactivity in DNA was measured by scintillation counter (Perkin Elmer, Waltham, MA, USA).

Wound-healing assay. SW480 and SW620 cells were seeded in a 6well culture plate at a density of $1.5 \times 10^{5}$ cells/well. After $12 \mathrm{~h}$, NOTUM siRNA and scrambled siRNA were added and plates were 
Table I. List of small interfering RNA (siRNA) sequences used in this study.

\begin{tabular}{|c|c|c|c|}
\hline \multirow[t]{2}{*}{ siRNA name } & & \multicolumn{2}{|c|}{ Sequence } \\
\hline & & Sense (5'-3') & Antisense ( $\left.5^{\prime}-3^{\prime}\right)$ \\
\hline Control & & UUCUCCGAACGUGUCACGUTT & ACGUGACACGUUCGGAGAATT \\
\hline \multirow[t]{3}{*}{ NOTUM } & $\# 1$ & AGTCTGAGAAGAACGAGTA & TACTCGTTCT TCTCAGACT \\
\hline & $\# 2$ & CCCTACTGGTGGAACGCAA & TTGCGTTCCA CCAGTAGGG \\
\hline & $\# 3$ & GGACAGCTTCATGGCGCAA & TTGCGCCATG AAGCTGTCC \\
\hline
\end{tabular}

incubated for another $72 \mathrm{~h}$. A wound was made by scratching in the central area of the plates with a pipette tip, and the detached cells were gently washed out. Cell migration was observed at 1, 12, 24, 36 , and $48 \mathrm{~h}$ after scratching. Images were taken of each wounded area under light microscopy.

Immunoblotting. Untreated cells were washed with $1 \times \mathrm{PBS}$ and lysed with lysis buffer $(150 \mathrm{mM} \mathrm{NaCl}, 10 \mathrm{mM}$ Tris- $\mathrm{HCl}, \mathrm{pH} 7.4,1 \%$ Triton X-100, $1 \mathrm{mM}$ ethylenediaminetetra-acetic acid $0.5 \%$ phenylmethylsulfonyl fluoride and $0.5 \%$ protease inhibitor). Human blood plasma was also lysed with the lysis buffer. Protein concentrations were measured by Bradford assay. Proteins $(10 \mu \mathrm{g}$ in each lane) were electrophoresed on $6-16 \%$ or $6-20 \%$ sodium dodecyl sulphate-polyacrylamide gels then transferred onto nitrocellulose membrane using the Hoefer wet transfer system. The membranes were blocked by tris buffered saline with tween 20 (TBS-T) buffer containing 5\% skimmed milk for $30 \mathrm{~min}$ and incubated for $18 \mathrm{~h}$ at $4^{\circ} \mathrm{C}$ with primary antibodies against NOTUM (Abcam), p110 $\alpha$ (Cell Signaling Technology), phosphorylated protein kinase B (pAKT) Ser473 Cell Signaling Technology), pAKT Thr308 (Cell Signaling Technology), AKT1/2 (Santa Cruz), phosphorylated extracellularsignal-regulated kinase (pERK) 1/2 Cell Signaling Technology), ERK1/2 (Cell Signaling Technology), cyclin D1 (Cell Signaling Technology), p-p38 (Thermo Fisher), p38 (Thermo Fisher), c-JUN $N$-terminal kinase1/2 (JNK1/2) (Cell Signaling Technology), pJNK1/2 (Cell Signaling Technology), $\beta$-actin (MP Biomedicals), and glyceraldehyde-3-phosphate dehydrogenase (GAPDH) (Cell Signaling Technology). After incubation, membranes were washed six times with TBS-T. The blots were incubated with horseradish peroxidase-conjugated anti-mouse, anti-rabbit (SeraCare, Milford, MA, USA), and anti-goat antibody (Santa Cruz, Dallas, TX, USA) for $2 \mathrm{~h}$ at room temperature with mild rotation. The membranes were washed with TBS-T six times and then developed by using electrochemiluminescence (ECL) solution (GE Healthcare). Western blot results were densitometrically analyzed using ImageJ (ver. 1.51).

Human tissue samples. Human blood plasma from healthy controls and patients with CRC were randomly selected by the National Cancer Center (South Korea). Participants provided informed consent, and protocols were approved by the Institutional Review Board of National Cancer Center (South Korea) (NCCCTS08351). All groups consisted of 42-to 77-year-olds without significant sex difference. Three healthy samples from controls (42 to 67 years old, two males, one female), three from patients with stage I (61 to 77 years old, males), seven with stage II (43 to 76 years old, four males, two females), nine with stage III (42 to 68 years old, six males, three females), and one with stage IV (63 years old, female) CRC samples were used. All plasma was collected by fine-needle aspiration during pre-operative blood draw and collected in tubes with heparin. All plasma was shipped within 1 day of collection, packed with dry ice and stored at $-80^{\circ} \mathrm{C}$ before analysis of NOTUM concentration.

ELISA. Plasma specimens were diluted $1 / 10$ with $100 \mathrm{mM}$ bicarbonate/carbonate buffer and coated onto a 96-well plate for $24 \mathrm{~h}$ at $4^{\circ} \mathrm{C}$. The plates were washed three times with PBS and blocked with $5 \%$ skimmed milk/PBS for $24 \mathrm{~h}$ at $4^{\circ} \mathrm{C}$. The plates were washed three times and incubated with primary antibody (ab106448; Abcam) for $2 \mathrm{~h}$ at room temperature. Next the plates were washed three times with $0.05 \%$ Tween-20 and incubated with horseradish peroxidase-conjugated goat anti-rabbit IgG secondary antibody for $2 \mathrm{~h}$ at room temperature. After three times washing with PBS, $100 \mu$ l of ultra tetramethyl benzidine solution was added to each well and incubated for $20 \mathrm{~min}$ at room temperature. Sulfuric acid (2 M) was treated to stop the reaction, and the absorbance was then measured at $450 \mathrm{~nm}$. Absorbance normalized by total protein amount was used as the absorbance index.

Statistical analysis. For the secretome study, proteins identified as differentially secreted between the two CRC cell lines were those with $t$-test $p<0.05$ obtained using an integrative statistical hypothesis testing, which combines F-tests obtained from two-tailed Student's $t$-test. Significance of proliferation and wound-healing assays was evaluated by two-tailed Student's $t$-test; differences with $p<0.05$ were considered statistically significant.

\section{Results}

Comparative proteomic analysis of SW480 and SW620 CRC cell lines. To compare the secretory protein profile of SW480 and SW620 CRC cell lines, we applied reliable label-free quantitative proteomics analysis. We identified 124 proteins from SW480 and SW620 cells in total. The list of representative proteins of which the levels differed significantly between the two cell lines is shown in Table II. To identify the biological features of the identified proteins, IPA was used. We directly applied the quantitative proteomic result to IPA. Five out of 10 canonical pathways were activated in the secretome of SW620 (z-score cutoff $=0.1,-\log (p$-value $)>1.3)$ (Figure 1B). Integrin linked 
kinase (ILK), actin cytoskeleton, RhoGDI, sirtuin, and 14-3-3-mediated signaling were activated, while actin-based mobility by Rho, leukocyte extravasation, RhoA, sumoylation, and Rho family GTPase signaling were deactivated in the secretome of SW620 (Figure 1B). This indicates that the canonical pathways involved in metastatic features of CRC (19) were changed. We plotted a virtual $2-\mathrm{D}$ protein map by using the fold change of protein expression in SW480 and SW620 against the total ion intensity (Figure 1C). We found a series of plots that showed an increase or decrease proportional to the increase or decrease of total ion intensity. This indicated reliability of the quantitative proteomic results.

We used three criteria to screen proteins for further study, namely whether the protein was increased in the secretome of SW620 cells compared with SW480 cells, whether it had signaling sequences, and whether its involvement in cancer progression was unknown (20-23). We selected NOTUM whose level was clearly increased in the secretome of SW620 cells $\left(\log _{2} R=6.78\right)$. We verified this increase by immunoblotting (Figure 1D). NOTUM is an extracellular enzyme induced by high levels of Wingless activity in Drosophila (24). It is anchored to the cell surface by binding to glypican-like sulfated proteoglycans, and it functions as a glypican-dependent Wnt inhibitor (25). NOTUM regulates head formation and neural induction in Xenopus (26), and activity of hedgehog proteins in Drosophila (27). Recently, its overexpression in some human hepatocellular carcinomas and CRCs has been reported $(28,29)$. We first verified intracellular and extracellular protein levels of NOTUM in CRC cell lines. The NOTUM level was found to be slightly increased in SW620 compared to SW480 in the whole cell lysate. However, the level of NOTUM was drastically increased in the conditioned medium of SW620 metastatic CRC cells (Figure 1D).

Secreted NOTUM affected proliferation of CRC cells. We hypothesized that the secreted NOTUM had a regulatory function in cancer progression because NOTUM was secreted by SW620 cells as shown in Figure 1D. We checked whether the neutralization of secreted NOTUM affected the proliferation of CRC cells. After treatment of both SW480 and SW620 cell lines with anti-NOTUM for $72 \mathrm{~h}$, the proliferative activities of SW480 and SW620 cells were found to be significantly reduced (Figure 2). Furthermore, the reductive effect was greater in SW620 than in SW480 cells. This indicates that secreted NOTUM has a role in CRC progression, and its effect is stronger in metastatic than in primary CRC cells.

Involvement of NOTUM in proliferation and migration of CRC cells. We performed knockdown of NOTUM gene in SW480 and SW620 calls using siRNAs. The efficacy of

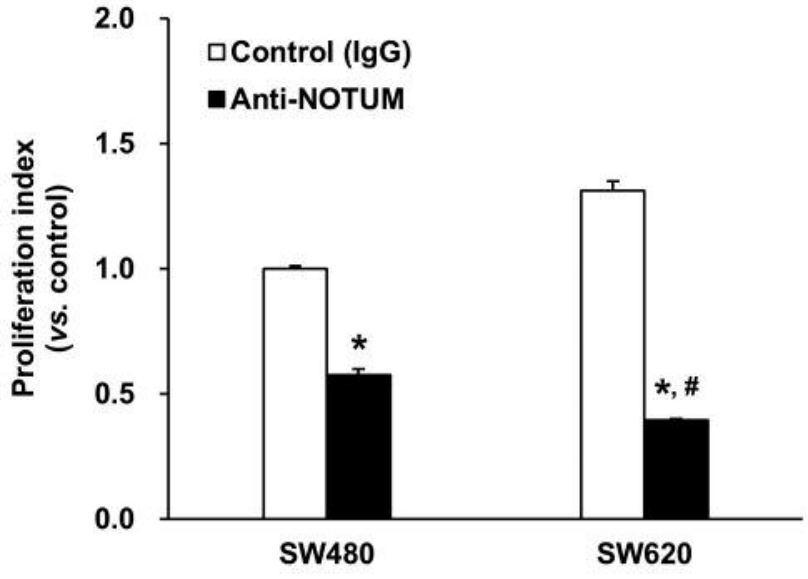

Figure 2. Proliferation of SW480 and SW620 colorectal cancer cells under palmitoleoyl-protein carboxylesterase (NOTUM) neutralization. Tetrazolium (MTT) assay for proliferation was performed in the presence of 400 nM antibody to NOTUM or control IgG. Data are shown as the mean \pm standard error of the mean. Significantly different at: ${ }^{*} p<0.05$ versus control IgG (two-tailed Student's t-test); \#p<0.05 against control IgG of SW480 (two-tailed Student's t-test).

knockdown is shown in Figure 3. Knockdown of NOTUM clearly reduced proliferative activity as measured by thymidine incorporation assay compared to the control, regardless of cell type (Figure 4A). Next, the migratory activity was determined using wound-healing assay after the knockdown of NOTUM. Migration of SW480 cells was assessed every $12 \mathrm{~h}$ and was found to be reduced from $12 \mathrm{~h}$ up to $48 \mathrm{~h}$, with statistical significance (Figure 4B). We also found that the reduction of migration SW620 cells was similar to that of SW480 cells (Figure 4C).

Up-regulation of p38 and JNK pathways due to NOTUM knockdown in CRC cells. It has been reported that stimulating AKT or mitogen-activated protein kinase (MAPK) pathways regulated CRC progression $(30,31)$. To understand the underlying mechanisms responsible for cell proliferation and migration induced by NOTUM in CRC, cells were treated with NOTUM siRNA or control siRNA and expression of AKT-, ERK-, p38-, and JNK-related signal molecules was analyzed. Firstly, we examined AKT signaling, which is generally known as a proliferative pathway in various cell types $(32,33)$. AKT-related signaling components including phosphatidylinositol 3kinase (PI3KCA) catalytic subunit (p110 $\alpha$ ), p-AKT, and AKT1/2 were not affected by NOTUM knockdown (Figure 5A). Expression of proteins of the ERK signaling pathway, p-ERK1/2, ERK1/2, and its downstream molecule cyclin D1 did not change (Figure 5B). On the other hand, 
Table II. List of representative proteins changed in conditioned media of SW480 and SW620 $\left(\log _{2}>2\right)$.

\begin{tabular}{|c|c|c|c|c|c|c|}
\hline Accession & Name & $\begin{array}{c}\text { Coverage } \\
(\%)\end{array}$ & $\begin{array}{l}\text { Mascot } \\
\text { score }\end{array}$ & $\begin{array}{l}\text { Unique } \\
\text { peptides }\end{array}$ & $\log _{2} \mathrm{R}$ & $p$-Value \\
\hline Q07654 & Trefoil factor 3 & 91.5 & 2722.91 & 60 & 12.32 & $<0.001$ \\
\hline P36955 & Pigment epithelium-derived factor & 32.1 & 4211.06 & 76 & 9.28 & 0.002 \\
\hline P12830 & Cadherin-1 & 4.4 & 1390.4 & 24 & 8.83 & $<0.001$ \\
\hline P05787 & Keratin, type II cytoskeletal 8 & 30 & 2638.85 & 52 & 8.74 & 0.025 \\
\hline P61769 & Beta-2-microglobulin & 30.6 & 1747.46 & 36 & 8.56 & 0.002 \\
\hline Q99574 & Neuroserpin & 29.4 & 3166.09 & 48 & 8.40 & 0.004 \\
\hline P00558 & Phosphoglycerate kinase 1 & 39.4 & 2182.86 & 43 & 8.13 & 0.004 \\
\hline P19338 & Nucleolin & 4.5 & 672.16 & 14 & 7.56 & 0.006 \\
\hline P98160 & Basement membrane-specific heparan sulfate proteoglycan core protein & 6.1 & 2812.95 & 75 & 7.47 & 0.037 \\
\hline $\mathrm{P} 24821$ & Tenascin & 3.8 & 1740.31 & 27 & 7.38 & 0.007 \\
\hline P19021 & Peptidyl-glycine alpha-amidating monooxygenase & 5 & 979.97 & 22 & 7.36 & 0.004 \\
\hline P07900 & Heat-shock protein (HSP 90-alpha) & 18.6 & 1094.84 & 27 & 7.25 & 0.010 \\
\hline P14543 & Nidogen-1 & 4.7 & 433.04 & 8 & 7.18 & 0.118 \\
\hline Q6P988 & Palmitoleoyl-protein carboxylesterase (NOTUM) & 6.9 & 1133.46 & 18 & 6.76 & 0.008 \\
\hline Q13740 & CD166 antigen & 2.5 & 353.83 & 8 & 6.31 & 0.053 \\
\hline O94985 & Calsyntenin-1 & 5.6 & 772.96 & 16 & 6.11 & 0.046 \\
\hline $\mathrm{P} 25311$ & Zinc-alpha-2-glycoprotein & 25.9 & 558.73 & 12 & 6.10 & 0.022 \\
\hline O94808 & Glutamine--fructose-6-phosphate aminotransferase (isomerizing) 2 & 1.3 & 229.29 & 9 & 6.06 & 0.120 \\
\hline Q5T2S8 & Armadillo repeat-containing protein 4 & 0.6 & 377.53 & 9 & 5.85 & 0.010 \\
\hline Q9GZX9 & Twisted gastrulation protein homolog 1 & 7.6 & 457.59 & 9 & 5.81 & $<0.001$ \\
\hline P01033 & Metalloproteinase inhibitor 1 & 59.2 & 4303.88 & 87 & 5.72 & 0.001 \\
\hline P04156 & Major prion protein & 5.8 & 478.9 & 9 & 5.68 & 0.251 \\
\hline P17096 & High mobility group protein HMG-I/HMG-Y & 23.6 & 169.18 & 4 & 5.60 & 0.354 \\
\hline Q92520 & Protein FAM3C & 6.4 & 393.52 & 7 & 5.47 & 0.001 \\
\hline P05783 & Keratin, type I cytoskeletal 18 & 13.5 & 685.88 & 22 & 5.36 & 0.011 \\
\hline P23284 & Peptidyl-prolyl cis-trans isomerase B & 11.5 & 90.98 & 4 & 5.36 & 0.122 \\
\hline $\mathrm{P} 11021$ & Endoplasmic reticulum chaperone $\mathrm{BiP}$ & 4.2 & 239.05 & 4 & 5.11 & 0.172 \\
\hline P13639 & Elongation factor 2 & 4.1 & 418.08 & 7 & 4.88 & 0.062 \\
\hline Q13308 & Inactive tyrosine-protein kinase 7 & 3 & 444.71 & 8 & 4.88 & 0.016 \\
\hline P10599 & Thioredoxin & 19.2 & 196.13 & 6 & 4.63 & 0.091 \\
\hline Q3ZBD7 & Glucose-6-phosphate isomerase & 4.9 & 120.99 & 5 & 4.43 & 0.308 \\
\hline P30101 & Protein disulfide-isomerase A3 & 2.5 & 172.61 & 4 & 4.42 & 0.207 \\
\hline P09341 & Growth-regulated alpha protein & 27.9 & 273.07 & 7 & 4.41 & 0.195 \\
\hline $\mathrm{P} 23142$ & Fibulin-1 & 8.3 & 275.82 & 5 & 4.40 & 0.127 \\
\hline O00299 & Chloride intracellular channel protein 1 & 7.5 & 216.28 & 3 & 4.23 & 0.176 \\
\hline Q01469 & Fatty acid-binding protein, epidermal & 20.1 & 245.73 & 8 & 4.19 & $<0.001$ \\
\hline P81605 & Dermcidin & 15.4 & 147.39 & 3 & 4.18 & 0.392 \\
\hline P52799 & Ephrin-B2 & 4.9 & 73.97 & 2 & 4.11 & 0.173 \\
\hline P09493 & Tropomyosin alpha-1 chain & 12.3 & 110.48 & 3 & 4.00 & 0.395 \\
\hline P20962 & Parathymosin & 16.8 & 489.45 & 11 & 3.91 & 0.332 \\
\hline P11142 & Heat-shock cognate $71 \mathrm{kDa}$ protein & 21.2 & 2779.18 & 57 & 3.80 & 0.033 \\
\hline P35579 & Myosin-9 & 0.8 & 542.21 & 6 & 3.70 & 0.014 \\
\hline Q14974 & Importin subunit beta- 1 & 1 & 88.83 & 3 & 3.62 & 0.256 \\
\hline P50395 & Rab GDP dissociation inhibitor beta & 7.4 & 146.11 & 4 & 3.60 & 0.144 \\
\hline P51888 & Prolargin & 2.5 & 83.11 & 4 & 3.56 & 0.002 \\
\hline P23526 & Adenosylhomocysteinase & 3.2 & 65.55 & 2 & 3.56 & 0.138 \\
\hline P16949 & Stathmin & 8.8 & 120.01 & 2 & 3.54 & 0.141 \\
\hline Q8NC51 & Plasminogen activator inhibitor 1 RNA-binding protein & 2 & 241.36 & 9 & 3.50 & 0.021 \\
\hline Q15582 & Transforming growth factor-beta-induced protein ig-h3 & 3.6 & 214.87 & 5 & 3.43 & 0.205 \\
\hline P52209 & 6-Phosphogluconate dehydrogenase, decarboxylating & 3.5 & 100.62 & 3 & 3.43 & 0.407 \\
\hline P02769 & Serum albumin & 42.4 & 4459.07 & 97 & 3.23 & 0.065 \\
\hline P08727 & Keratin, type I cytoskeletal 19 & 9.8 & 174.2 & 2 & 3.18 & 0.283 \\
\hline O60568 & Procollagen-lysine,2-oxoglutarate 5-dioxygenase 3 & 2.2 & 79.45 & 2 & 3.10 & 0.147 \\
\hline P21926 & CD9 antigen & 10.6 & 128.69 & 3 & 3.08 & 0.223 \\
\hline P10145 & Interleukin-8 & 47.8 & 62.38 & 2 & 3.08 & 0.372 \\
\hline $\mathrm{P} 22692$ & Insulin-like growth factor-binding protein 4 & 16 & 1275.9 & 12 & 2.85 & 0.079 \\
\hline P31946 & 14-3-3 protein beta/alpha & 9.8 & 140.46 & 5 & 2.84 & 0.220 \\
\hline
\end{tabular}


Table II. Continued

\begin{tabular}{|c|c|c|c|c|c|c|}
\hline Accession & Name & $\begin{array}{c}\text { Coverage } \\
(\%)\end{array}$ & $\begin{array}{c}\text { Mascot } \\
\text { score }\end{array}$ & $\begin{array}{l}\text { Unique } \\
\text { peptides }\end{array}$ & $\log _{2} \mathrm{R}$ & $p$-Value \\
\hline P43243 & Matrin-3 & 2.1 & 67.86 & 2 & 2.78 & 0.163 \\
\hline Q05716 & Insulin-like growth factor-binding protein 4 & 9.3 & 757.1 & 15 & 2.71 & 0.001 \\
\hline Q9Y6N7 & Roundabout homolog 1 & 1.5 & 289.91 & 9 & 2.69 & 0.249 \\
\hline P55001 & Microfibrillar-associated protein 2 & 12.7 & 351.74 & 8 & 2.57 & 0.091 \\
\hline P68133 & Actin, alpha skeletal muscle & 9.9 & 1260.71 & 28 & 2.48 & 0.002 \\
\hline Q9H1U9 & Solute carrier family 25 member 51 & 2.4 & 158.84 & 2 & 2.35 & 0.223 \\
\hline P40926 & Malate dehydrogenase, mitochondrial & 17.8 & 805.35 & 10 & 2.31 & 0.127 \\
\hline P05067 & Amyloid-beta A4 protein & 28.9 & 5973.29 & 111 & 2.29 & 0.007 \\
\hline Q9BRK5 & $45 \mathrm{kDa}$ calcium-binding protein & 3.1 & 92.67 & 3 & 2.17 & 0.193 \\
\hline Q13421 & Mesothelin & 8.4 & 85.51 & 3 & 2.12 & 0.302 \\
\hline P06748 & Nucleophosmin & 10.9 & 1151.78 & 24 & -2.49 & 0.046 \\
\hline P09382 & Galectin-1 & 13.4 & 1339.73 & 22 & -2.51 & 0.001 \\
\hline P07355 & Annexin A2 & 7.7 & 1433.65 & 32 & -2.99 & 0.066 \\
\hline P24534 & Elongation factor 1-beta & 10.7 & 122.9 & 4 & -3.20 & 0.155 \\
\hline Q8NBJ4 & Golgi membrane protein 1 & 2.7 & 48.6 & 2 & -3.90 & 0.262 \\
\hline P18065 & Insulin-like growth factor-binding protein 2 & 24.8 & 845.48 & 16 & -4.11 & 0.104 \\
\hline P00441 & Superoxide dismutase $(\mathrm{Cu}-\mathrm{Zn})$ & 69.9 & 4403.06 & 97 & -4.99 & 0.002 \\
\hline P68104 & Elongation factor 1 -alpha 1 & 10 & 203.27 & 5 & -6.41 & 0.173 \\
\hline P61604 & $10 \mathrm{kDa}$ heat shock protein, mitochondrial & 26.7 & 154.55 & 4 & -6.96 & 0.169 \\
\hline P10909 & Clusterin & 6.3 & 184.5 & 3 & -7.76 & 0.018 \\
\hline Q99435 & Protein kinase C-binding protein NELL2 & 9.3 & 234.53 & 6 & -7.88 & 0.121 \\
\hline Q86TH1 & ADAMTS-like protein 2 & 4.4 & 229.28 & 5 & -9.54 & 0.117 \\
\hline P16070 & CD44 antigen & 4.7 & 1193.63 & 23 & -9.94 & 0.001 \\
\hline Q9UBT3 & Dickkopf-related protein 4 & 15 & 1733.23 & 41 & -10.94 & 0.006 \\
\hline P01037 & Cystatin-SN & 46.3 & 1075.85 & 25 & -11.50 & 0.009 \\
\hline Q16270 & Insulin-like growth factor-binding protein 7 & 23.8 & 449.39 & 9 & -11.74 & $<0.001$ \\
\hline
\end{tabular}

although the levels of p38 and JNK1/2 were not affected by NOTUM knockdown (Figure 6A), phosphorylated p38, and JNK $1 / 2$ levels under NOTUM knockdown increased compared to the control (Figure 6A and B). In addition, the levels of p-JNK1 and p-p38 were higher in SW620 than those in SW480 cells (Figure 6A and B). These data indicate that NOTUM induced cell proliferation and migration via JNK and p38 MAPK inhibition, especially in metastatic CRC cells.

Increase in plasma NOTUM level in patients with CRC. We finally tried to verify reliability and applicability of NOTUM in diagnostics and treatment of patients with CRC. Twentythree blood specimens from groups of healthy controls and stage-divided CRC patients. Using ELISA, we found a clear increase in absorbance in plasma of patients with CRC compared to the healthy controls (Figure 7A). This observation indicates reliability of our results and suggests NOTUM to be a potential biomarker of CRC. The plasma NOTUM level was the highest in patients with stage I CRC (Figure 7B). We also performed immunoblotting for NOTUM in plasma and found that the plasma NOTUM level was higher in patients with CRC (Figure 8).

\section{Discussion}

We profiled 124 proteins from the secretome of isogenic primary and metastatic CRC cells using reliable label-free quantitative proteomic analysis. Providing fundamental data for elucidation of CRC, we identified NOTUM as a candidate CRC-specific biomarker and therapeutic target. Based on our experimental results, NOTUM was associated with proliferation and migration of CRC cells and we the regulation of phosphorylation of p38 and JNK. The NOTUM level was elevated in plasma of patients with CRC (Figure 7). This result suggests the high potential of NOTUM to be developed as a biomarker and therapeutic target for CRC.

NOTUM is a $56-\mathrm{kDa}$ evolutionarily-conserved secreted deacylase that regulates Wnt signaling activity (26). Earlier studies have shown that NOTUM regulates development in Drosophila, while its function in mammals was only recently characterized (25). NOTUM is overexpressed in hepatocellular carcinoma (28) and is also related to gastric cancer (34). These observations suggest that NOTUM has a role in other cancer types but do not provide any association between NOTUM and CRC. A recently published report demonstrated that the NOTUM level in colon mucosae was enhanced in a mouse 


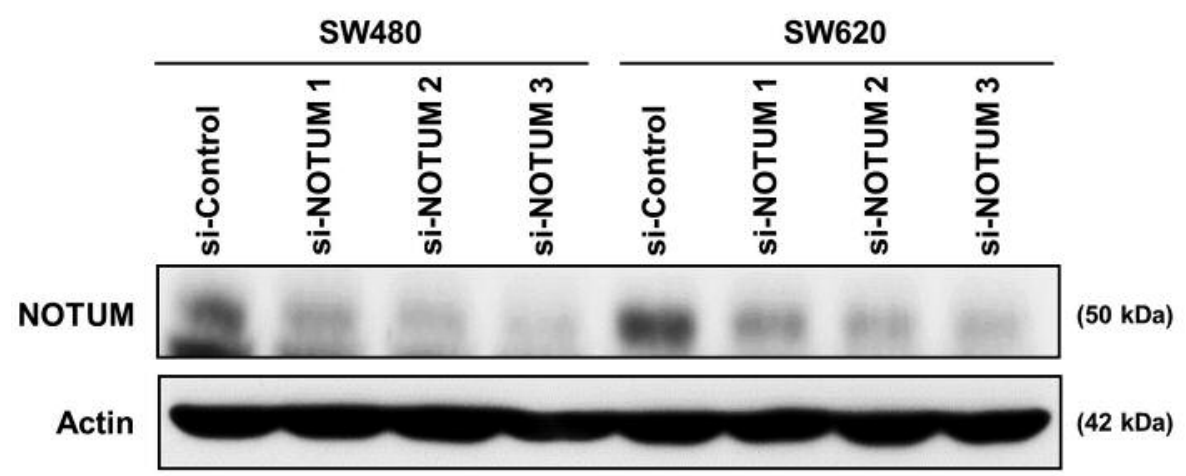

Figure 3. Efficacy of palmitoleoyl-protein carboxylesterase (NOTUM) knockdown. Immunoblot analysis for NOTUM knockdown efficiency after small interfering RNA (siRNA) treatment. NOTUM knockdown efficacy was 30-40\%.

A

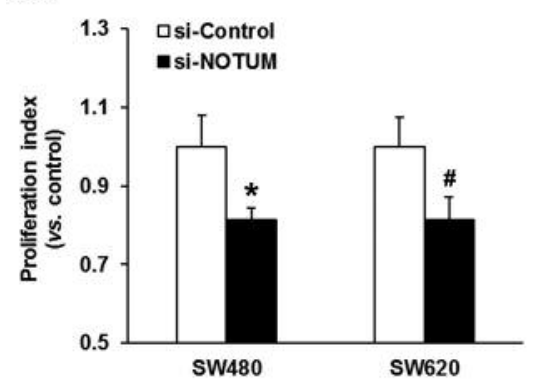

C

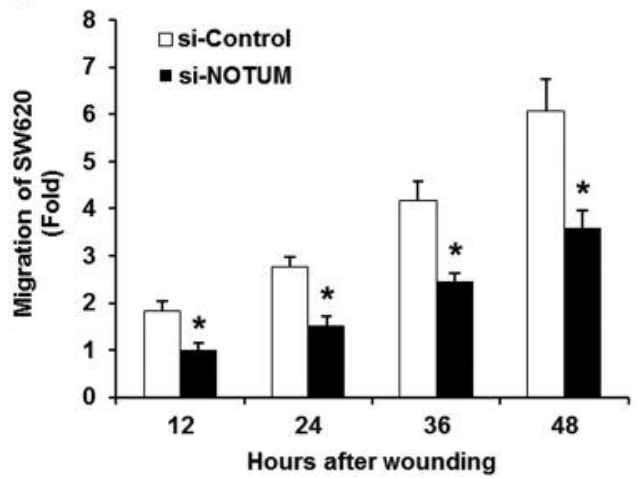

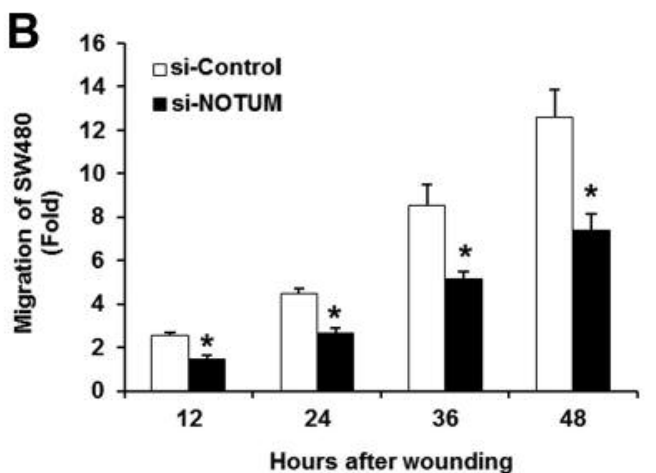
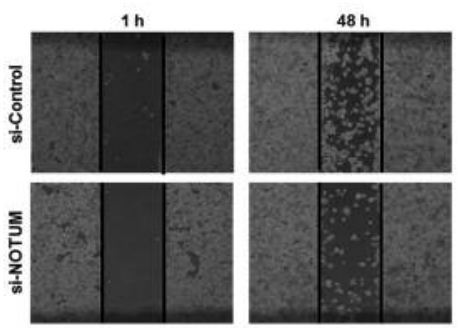

Figure 4. Proliferation and migration assays after palmitoleoyl-protein carboxylesterase (NOTUM) knockdown SW480 and SW620 colorectal cancer cells. A: Thymidine incorporation assay for the measurement of proliferation of control or NOTUM siRNA-transfected cells. Wound-healing assay for measurement of migration of SW480 (B) and SW620 (C) cells under NOTUM knockdown. After treatment with small interfering RNA (siRNA), the cell layer was scratched with a sterile pipette tip, and measurement of migrated cells was performed at 12, 24, 36, and 48 h. Images were taken using a $4 \times$ objective. Data are shown as the mean \pm standard error of the mean, $n=5$. *Significantly different at $p<0.05$ compared with the control; \#p=0.06.

model of CRC (29). In line with this observation, we found that the NOTUM level increased in the secretome of human metastatic CRC cells. Moreover, NOTUM was found to be required for proliferation and migration of CRC cells regardless of their aggressiveness (Figure 4). Because two phenotypes such as proliferation and migration are difficult to completely distinguish in cancer, further study is needed to determine whether NOTUM changes the Rho GTPase 

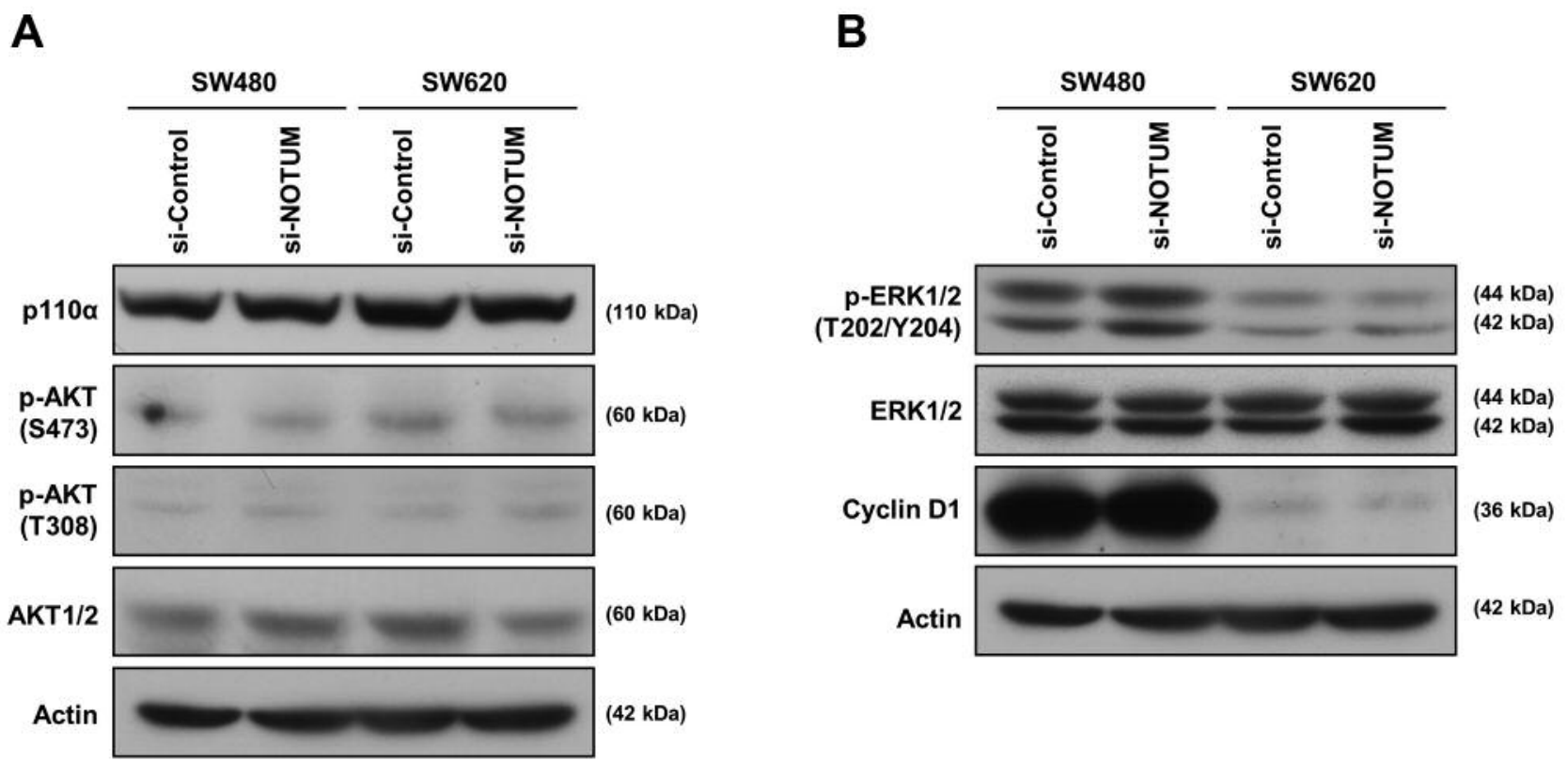

Figure 5. Immunoblotting of proteins of signal pathways after palmitoleoyl-protein carboxylesterase (NOTUM) knockdown in SW480 and SW620 colorectal cancer cells. Immunoblot analysis of p110 $\alpha$, phosphorylated protein kinase B (p-AKT), and AKT1/2 (A), phosphorylated extracellularsignal-regulated kinase 1/2 (p-ERK1/2), ERK1/2 and cyclin D1 (B) in SW480 and SW620 cells after NOTUM knockdown. $\beta$-Actin was used as a loading control.

signaling pathway and cell morphology appropriate for migration to confirm NOTUM increases cell migration. Taken together we suggest the possibility that NOTUM is a new biomarker as well as therapeutic target of CRC.

NOTUM was increased in plasma of patients with earlystage CRC rather than in late-stage (Figure 7). Because we observed this phenomenon using two proven experimental methods, we conclude that NOTUM can be used for diagnosis of early-stage CRC. It is known that colon cancer can be initiated and grow through the colon wall without metastasis at an early stage. When we consider lymph node or distant metastasis was observed from patients with stage III CRC at which the prognosis rapidly deteriorated $(35,36)$, we hypothesize that the potential role of NOTUM in CRC would be to initiate or support cancer cell growth to proceed to late stage disease. Once these cells have acquired vigorous metastatic characteristics, NOTUM would no longer be required for cancer progression.

In our study, phosphorylation of JNK and p38 was upregulated under NOTUM knockdown (Figure 6). NOTUM cleaves members of the glypican family related to Wnt, Hedgehog, transforming growth factor $\beta$ (TGF- $\beta$ ), and bone morphogenetic protein signaling $(25,37,38)$. Because glypicans maintain secreted signaling molecules at the cell surface to activate high-affinity signaling receptors and ensure activation of target genes, NOTUM, as a lipase, can act as a negative regulator of growth factors (39-42). It has been reported that TGF- $\beta$ suppresses tumorigenesis (43-46). The involvement of the p38 MAPK pathway in cell survival is well established (47-49). p38 $\alpha$ negatively regulates cellcycle progression and induces apoptosis (50). Moreover, mice with liver-specific deletion of $\mathrm{p} 38 \alpha$ developed more liver tumors (50). Another report showed that $\mathrm{p} 38 \alpha$ activity was down-regulated in human hepatocellular carcinoma (51). Regarding JNK, although there is increasing evidence of JNK-mediated apoptosis $(52,53)$, its involvement in cancer remains unresolved. On the other hand, mothers against decapentaplegic homolog 7 (SMAD7) and transforming growth factor B-activated kinase 1 (TAK1) induce apoptosis via the TGF- $\beta$ pathway through $\mathrm{p} 38$ and JNK activation (54). Recently, a report showed that JNK and p38 MAPK pathways are also related to CRC (55). We suggest the possibility that NOTUM inhibition may induce TGF- $\beta$ mediated p38 and JNK signaling, and suppress cell proliferation and migration, although mechanistic studies are required to elucidate this.

\section{Acknowledgements}

The Authors thank the National Cancer Center (Republic of Korea) that provided blood plasma samples. This research was supported by GRL Program (NRF-2016K1A1A2912722) and by KBRI basic research program (18-BR-02-01), funded by Ministry of Science 


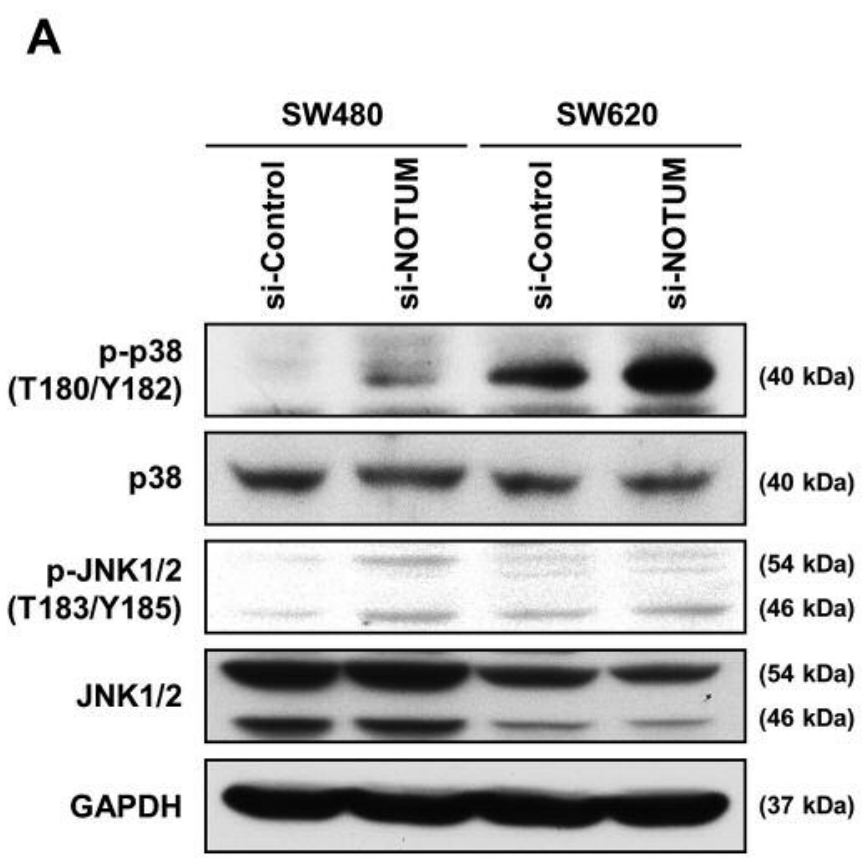

Figure 6. Palmitoleoyl-protein carboxylesterase (NOTUM) promotes progression of colorectal cancer by modulating p38 and c-JUN $N$-terminal kinase (JNK) pathways. A: Immunoblot analysis of p38 and JNK activity in SW480 and SW620 cells with NOTUM knockdown. $B$ : Relative density of protein bands was measured by ImageJ software and normalized to that of si-control SW480 cells.

and ICT. This research was supported by Basic Science Research Program through the National Research Foundation of Korea funded by the Ministry of Education (2018R1D1A1B07043929). This research was also supported by grants from the National Cancer Center, Republic of Korea (NCC 1810861-1).

\section{References}

1 Ferlay J, Soerjomataram I, Dikshit R, Eser S, Mathers C, Rebelo M, Parkin DM, Forman D and Bray F: Cancer incidence and mortality worldwide: Sources, methods and major patterns in GLOBOCAN 2012. Int J Cancer 136(5): E359-386, 2015.

2 Arnold M, Sierra MS, Laversanne M, Soerjomataram I, Jemal A and Bray F: Global patterns and trends in colorectal cancer incidence and mortality. Gut 66(4): 683-691, 2017.

3 Brenner H, Stock C and Hoffmeister M: Effect of screening sigmoidoscopy and screening colonoscopy on colorectal cancer incidence and mortality: Systematic review and meta-analysis of
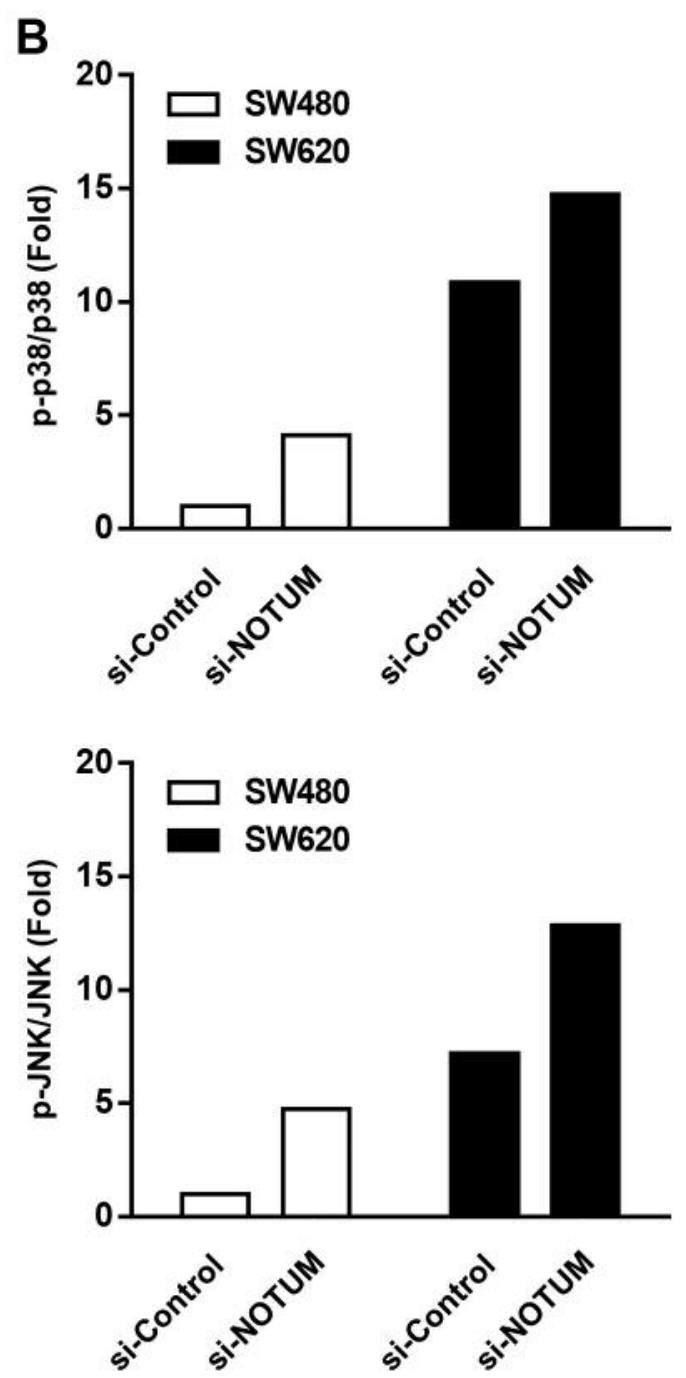

randomised controlled trials and observational studies. BMJ 348 : g2467, 2014.

4 Zauber AG: The impact of screening on colorectal cancer mortality and incidence: Has it really made a difference? Dig Dis Sci 60(3): 681-691, 2015.

5 Lansdorp-Vogelaar I, Knudsen $\mathrm{AB}$ and Brenner H: Costeffectiveness of colorectal cancer screening. Epidemiol Rev 33: 88-100, 2011.

6 Hassan C, Giorgi Rossi P, Camilloni L, Rex DK, JimenezCendales B, Ferroni E, Borgia P, Zullo A, Guasticchi G and Group HTA: Meta-analysis: Adherence to colorectal cancer screening and the detection rate for advanced neoplasia, according to the type of screening test. Aliment Pharmacol Ther 36(10): 929-940, 2012.

7 van der Schouw YT, Verbeek AL, Wobbes T, Segers MF and Thomas CM: Comparison of four serum tumour markers in the diagnosis of colorectal carcinoma. Br J Cancer 66(1): 148-154, 1992. 

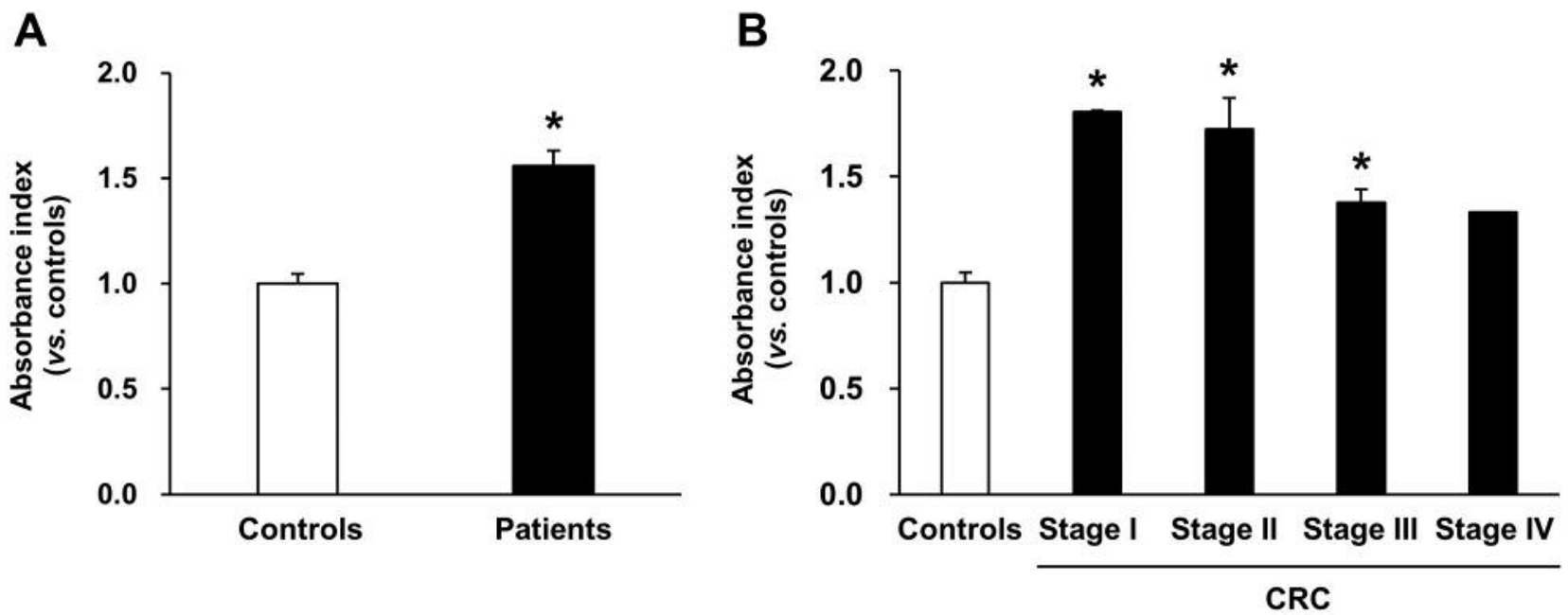

Figure 7. Plasma palmitoleoyl-protein carboxylesterase (NOTUM) levels, as determined by enzyme-linked immunosorbent assay in patients with colorectal cancer (CRC) and healthy individuals. A: Plasma NOTUM levels for healthy and CRC patient groups. B: Plasma NOTUM levels for healthy and patient groups according to CRC stage. Data are shown as the mean \pm standard error of the mean. *Significantly different at $p<0.05$ versus healthy controls.

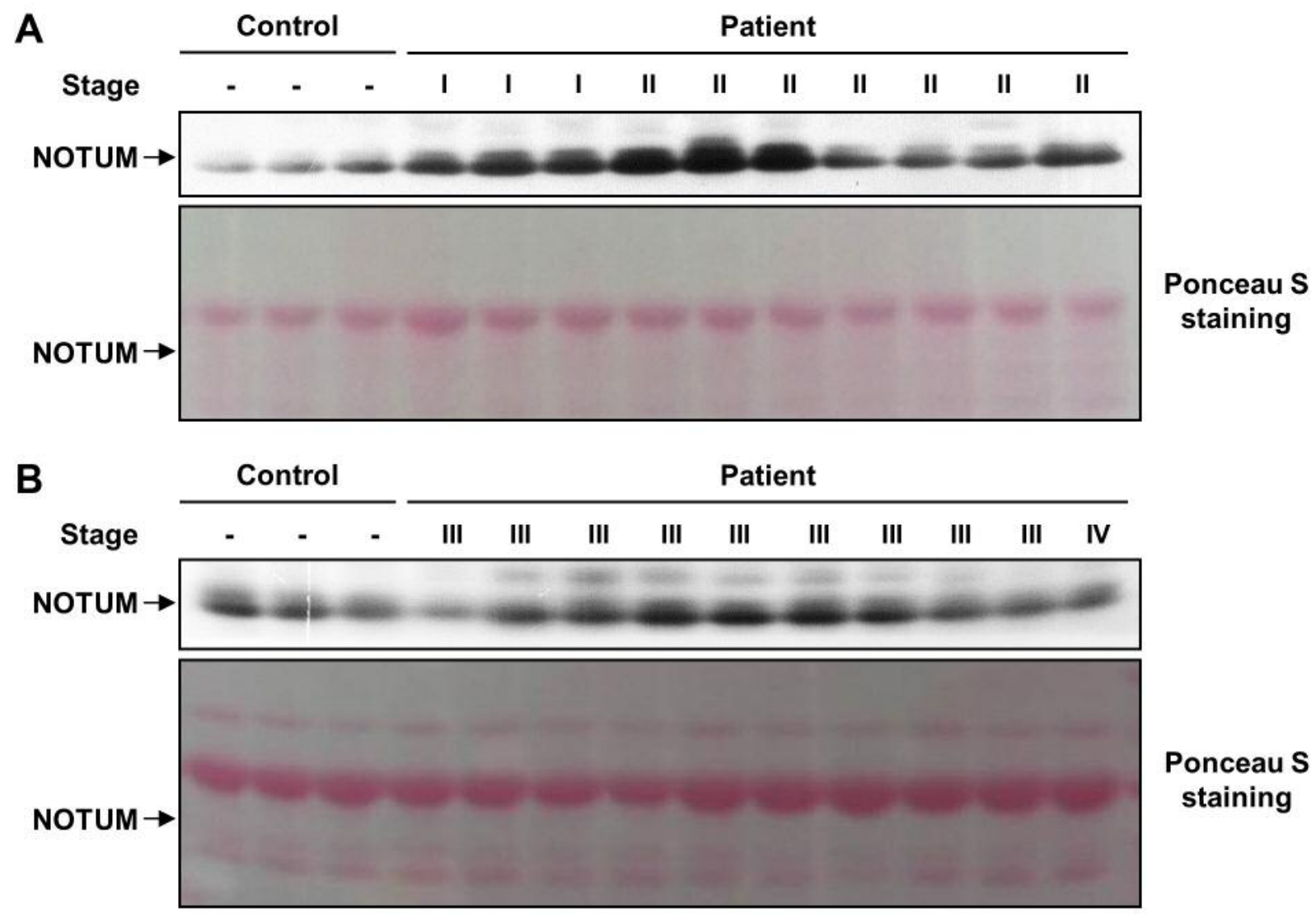

Figure 8. Immunoblotting of palmitoleoyl-protein carboxylesterase (NOTUM) in plasma of healthy controls and patients with colorectal cancer $(C R C)$. A: Healthy controls and patients with stage II CRC. B: Healthy controls and patients with stage II-IV CRC. Ponceau S-stained membranes are presented as protein loading controls. 
8 Kharaishvili G, Simkova D, Bouchalova K, Gachechiladze M, Narsia $\mathrm{N}$ and Bouchal $\mathrm{J}$ : The role of cancer-associated fibroblasts, solid stress and other microenvironmental factors in tumor progression and therapy resistance. Cancer Cell Int 14: 41, 2014.

9 Hanahan D and Weinberg RA: Hallmarks of cancer: The next generation. Cell 144(5): 646-674, 2011.

10 Wels J, Kaplan RN, Rafii S and Lyden D: Migratory neighbors and distant invaders: Tumor-associated niche cells. Genes Dev 22(5): 559-574, 2008.

11 Xue H, Lu B, Zhang J, Wu M, Huang Q, Wu Q, Sheng H, Wu $\mathrm{D}, \mathrm{Hu} \mathrm{J}$ and Lai $\mathrm{M}$ : Identification of serum biomarkers for colorectal cancer metastasis using a differential secretome approach. J Proteome Res 9(1): 545-555, 2010.

12 de Wit M, Kant H, Piersma SR, Pham TV, Mongera S, van Berkel MP, Boven E, Ponten F, Meijer GA, Jimenez CR and Fijneman RJ: Colorectal cancer candidate biomarkers identified by tissue secretome proteome profiling. J Proteomics 99: 26-39, 2014.

13 Ahmed D, Eide PW, Eilertsen IA, Danielsen SA, Eknaes M, Hektoen M, Lind GE and Lothe RA: Epigenetic and genetic features of 24 colon cancer cell lines. Oncogenesis 2: e71, 2013.

14 Gagos S, Hopwood VL, Iliopoulos D, Kostakis A, Karayannakos P, Yatzides H, Skalkeas GD and Pathak S: Chromosomal markers associated with metastasis in two colon cancer cell lines established from the same patient. Anticancer Res 15(2): 369378,1995 .

15 Ji H, Greening DW, Barnes TW, Lim JW, Tauro BJ, Rai A, Xu R, Adda C, Mathivanan S, Zhao W, Xue Y, Xu T, Zhu HJ and Simpson RJ: Proteome profiling of exosomes derived from human primary and metastatic colorectal cancer cells reveal differential expression of key metastatic factors and signal transduction components. Proteomics 13(10-11): 1672-1686, 2013.

16 Choi DS, Choi DY, Hong BS, Jang SC, Kim DK, Lee J, Kim YK, Kim KP and Gho YS: Quantitative proteomics of extracellular vesicles derived from human primary and metastatic colorectal cancer cells. J Extracell Vesicles 1, 2012. doi: $10.3402 /$ jev.v1i0.18704

17 Elias JE and Gygi SP: Target-decoy search strategy for increased confidence in large-scale protein identifications by mass spectrometry. Nat Methods 4(3): 207-214, 2007.

18 Griffin NM, Yu J, Long F, Oh P, Shore S, Li Y, Koziol JA and Schnitzer JE: Label-free, normalized quantification of complex mass spectrometry data for proteomic analysis. Nat Biotechnol 28(1): 83-89, 2010.

19 Young GM, Radhakrishnan VM, Centuori SM, Gomes CJ and Martinez JD: Comparative analysis of 14-3-3 isoform expression and epigenetic alterations in colorectal cancer. BMC Cancer 15: $826,2015$.

20 Yoon JH, Kim D, Jang JH, Ghim J, Park S, Song P, Kwon Y, Kim J, Hwang D, Bae YS, Suh PG, Berggren PO and Ryu SH: Proteomic analysis of the palmitate-induced myotube secretome reveals involvement of the annexin A1-formyl peptide receptor 2 (FPR2) pathway in insulin resistance. Mol Cell Proteomics 14(4): 882-892, 2015.

21 Yoon JH, Kim J, Kim KL, Kim DH, Jung SJ, Lee H, Ghim J, Kim D, Park JB, Ryu SH and Lee TG: Proteomic analysis of hypoxia-induced U373MG glioma secretome reveals novel hypoxia-dependent migration factors. Proteomics 14(12): 1494$1502,2014$.
22 Yoon JH, Song P, Jang JH, Kim DK, Choi S, Kim J, Ghim J, Kim D, Park S, Lee H, Kwak D, Yea K, Hwang D, Suh PG and Ryu SH: Proteomic analysis of tumor necrosis factor-alpha (TNF-alpha)-induced 16 myotube secretome reveals novel tnfalpha-dependent myokines in diabetic skeletal muscle. J Proteome Res 10(12): 5315-5325, 2011.

23 Yoon JH, Yea K, Kim J, Choi YS, Park S, Lee H, Lee CS, Suh PG and Ryu SH: Comparative proteomic analysis of the insulininduced 16 myotube secretome. Proteomics 9(1): 51-60, 2009.

24 Giraldez AJ, Copley RR and Cohen SM: HSPG modification by the secreted enzyme notum shapes the wingless morphogen gradient. Dev Cell 2(5): 667-676, 2002.

25 Traister A, Shi W and Filmus J: Mammalian NOTUM induces the release of glypicans and other GPI-anchored proteins from the cell surface. Biochem J 410(3): 503-511, 2008.

26 Zhang X, Cheong SM, Amado NG, Reis AH, MacDonald BT, Zebisch M, Jones EY, Abreu JG and He X: NOTUM is required for neural and head induction via wnt deacylation, oxidation, and inactivation. Dev Cell 32(6): 719-730, 2015.

27 Ayers KL, Gallet A, Staccini-Lavenant L and Therond PP: The long-range activity of hedgehog is regulated in the apical extracellular space by the glypican dally and the hydrolase notum. Dev Cell 18(4): 605-620, 2010.

28 Torisu Y, Watanabe A, Nonaka A, Midorikawa Y, Makuuchi M, Shimamura T, Sugimura H, Niida A, Akiyama T, Iwanari H, Kodama T, Zeniya $\mathrm{M}$ and Aburatani H: Human homolog of NOTUM, overexpressed in hepatocellular carcinoma, is regulated transcriptionally by beta-catenin/TCF. Cancer Sci 99(6): 1139-1146, 2008.

29 De Robertis M, Arigoni M, Loiacono L, Riccardo F, Calogero RA, Feodorova Y, Tashkova D, Belovejdov V, Sarafian V, Cavallo F and Signori E: Novel insights into NOTUM and glypicans regulation in colorectal cancer. Oncotarget 6(38): 41237-41257, 2015.

30 Fang JY and Richardson BC: The MAPK signalling pathways and colorectal cancer. Lancet Oncol 6(5): 322-327, 2005.

$31 \mathrm{Wu}$ WK, Wang XJ, Cheng AS, Luo MX, Ng SS, To KF, Chan FK, Cho CH, Sung JJ and Yu J: Dysregulation and crosstalk of cellular signaling pathways in colon carcinogenesis. Crit Rev Oncol Hematol 86(3): 251-277, 2013.

32 Velho S, Oliveira C, Ferreira A, Ferreira AC, Suriano G, Schwartz S Jr., Duval A, Carneiro F, Machado JC, Hamelin R and Seruca R: The prevalence of PIK3CA mutations in gastric and colon cancer. Eur J Cancer 41(11): 1649-1654, 2005.

33 Campbell IG, Russell SE, Choong DY, Montgomery KG, Ciavarella ML, Hooi CS, Cristiano BE, Pearson RB and Phillips WA: Mutation of the PIK3CA gene in ovarian and breast cancer. Cancer Res 64(21): 7678-7681, 2004.

34 Madan B, Ke Z, Lei ZD, Oliver FA, Oshima M, Lee MA, Rozen $\mathrm{S}$ and Virshup DM: NOTUM is a potential pharmacodynamic biomarker of WNT pathway inhibition. Oncotarget 7(11): 1238612392, 2016.

35 Kuipers EJ, Grady WM, Lieberman D, Seufferlein T, Sung JJ, Boelens PG, van de Velde CJ and Watanabe T: Colorectal cancer. Nat Rev Dis Primers 1: 15065, 2015.

36 Puccini A, Berger MD, Zhang W and Lenz HJ: What we know about c-JUN ii and iii colon cancer: It's still not enough. Target Oncol 12(3): 265-275, 2017.

37 Gao W and Ho M: The role of glypican-3 in regulating WNT in hepatocellular carcinomas. Cancer Rep 1(1): 14-19, 2011. 
38 Kayed H, Kleeff J, Keleg S, Jiang X, Penzel R, Giese T, Zentgraf H, Buchler MW, Korc M and Friess H: Correlation of glypican-1 expression with TGF-beta, BMP, and activin receptors in pancreatic ductal adenocarcinoma. Int $\mathrm{J}$ Oncol 29(5): 1139-1148, 2006.

39 Hacker U, Nybakken K and Perrimon N: Heparan sulphate proteoglycans: The sweet side of development. Nat Rev Mol Cell Biol 6(7): 530-541, 2005.

40 Filmus J, Capurro M and Rast J: Glypicans. Genome Biol 9(5): 224, 2008

41 Dreyfuss JL, Regatieri CV, Jarrouge TR, Cavalheiro RP, Sampaio LO and Nader HB: Heparan sulfate proteoglycans: Structure, protein interactions and cell signaling. An Acad Bras Cienc 81(3): 409-429, 2009.

42 Cassinelli G, Zaffaroni N and Lanzi C: The heparanase/heparan sulfate proteoglycan axis: A potential new therapeutic target in sarcomas. Cancer Lett 382(2): 245-254, 2016.

43 David CJ, Huang YH, Chen M, Su J, Zou Y, Bardeesy N, Iacobuzio-Donahue $\mathrm{CA}$ and Massague J: TGF-beta tumor suppression through a lethal emt. Cell 164(5): 1015-1030, 2016.

44 Li J, Ballim D, Rodriguez M, Cui R, Goding CR, Teng H and Prince S: The anti-proliferative function of the TGF-betal signaling pathway involves the repression of the oncogenic TBX2 by its homologue TBX3. J Biol Chem 289(51): 3563335643, 2014.

45 Jahn SC, Law ME, Corsino PE and Law BK: TGF-beta antiproliferative effects in tumor suppression. Front Biosci 4: 749-766, 2012.

46 Zhang YE: Non-smad pathways in tgf-beta signaling. Cell Res 19(1): 128-139, 2009.

47 Engel FB, Schebesta M, Duong MT, Lu G, Ren S, Madwed JB, Jiang $\mathrm{H}$, Wang $\mathrm{Y}$ and Keating MT: P38 MAP kinase inhibition enables proliferation of adult mammalian cardiomyocytes. Genes Dev 19(10): 1175-1187, 2005

48 Hui L, Bakiri L, Mairhorfer A, Schweifer N, Haslinger C, Kenner L, Komnenovic V, Scheuch H, Beug H and Wagner EF: P38alpha suppresses normal and cancer cell proliferation by antagonizing the JNK-c-JUN pathway. Nat Genet 39(6): 741$749,2007$.
49 Ventura JJ, Tenbaum S, Perdiguero E, Huth M, Guerra C, Barbacid M, Pasparakis $M$ and Nebreda AR: P38alpha MAP kinase is essential in lung stem and progenitor cell proliferation and differentiation. Nat Genet 39(6): 750-758, 2007.

50 Hui L, Bakiri L, Stepniak E and Wagner EF: P38alpha: A suppressor of cell proliferation and tumorigenesis. Cell Cycle 6(20): 2429-2433, 2007.

51 Iyoda K, Sasaki Y, Horimoto M, Toyama T, Yakushijin T, Sakakibara M, Takehara T, Fujimoto J, Hori M, Wands JR and Hayashi N: Involvement of the p38 mitogen-activated protein kinase cascade in hepatocellular carcinoma. Cancer 97(12): 3017-3026, 2003.

52 Ventura JJ, Hubner A, Zhang C, Flavell RA, Shokat KM and Davis RJ: Chemical genetic analysis of the time course of signal transduction by JNK. Mol Cell 21(5): 701-710, 2006.

53 Deng Y, Ren X, Yang L, Lin Y and Wu X: A JNK-dependent pathway is required for TNFalpha-induced apoptosis. Cell 115(1): 61-70, 2003

54 Edlund S, Bu S, Schuster N, Aspenstrom P, Heuchel R, Heldin NE, ten Dijke P, Heldin CH and Landstrom M: Transforming growth factor-beta1 (TGF-beta)-induced apoptosis of prostate cancer cells involves SMAD7-dependent activation of p38 by TGF-beta-activated kinase 1 and mitogen-activated protein kinase kinase 3. Mol Biol Cell 14(2): 529-544, 2003.

55 Huang DY, Chao Y, Tai MH, Yu YH and Lin WW: STI571 reduces trail-induced apoptosis in colon cancer cells: C-ABL activation by the death receptor leads to stress kinase-dependent cell death. J Biomed Sci 19: 35, 2012.
Received July 24, 2018

Revised September 14, 2018

Accepted September 19, 2018 